\title{
硬ロウ材の高温機械的性質についで
}

\author{
江国定明**平井淳一** 吉田啓一**

\section{Mechanical Properties of Brazing Filler Alloys at Elevated Temperatures*}

By Sadaaki Ekuni**, Junichi Hirai** and Keiichi Yoshida**

\begin{abstract}
In using the brazed joint at high temperature, we have thought that the strength of brazed joints is related to the mechanical properties of brazing filler alloys at elevated temperatures. In this study, we adopted nine kinds of brazing filler alloy composed of $\mathrm{Ag}-\mathrm{P}-\mathrm{Cu}, \mathrm{Ag}-\mathrm{Cu}-\mathrm{Zn}-\mathrm{Cd}$ and $\mathrm{Cu}-\mathrm{Zn}$ systems that were used for brazing copper and copper alloys, and tested their tensile strength, elongation and hardness in the range from the room temperature to $500^{\circ} \mathrm{C}$.
\end{abstract}

The test results are summarized as follows;

1) Ag-P-Cu systems

With an increasing content of $\mathrm{Ag}$, the mechanical properties at the room and elevated temperatures improved, and a filler alloy of $5 \% \mathrm{Ag}$ is stronger than one of $15 \% \mathrm{Ag}$ at the temperature under $250^{\circ} \mathrm{C}$, but at over $250^{\circ} \mathrm{C}$, the opposite is true.

2) $\mathrm{Ag}-\mathrm{Cu}-\mathrm{Zu}-\mathrm{Cd}$ systems

No definite relationship was found between $\mathrm{Ag}$ content and mechanical properties at elevated temperatures.

3) The mechanical properties of $\mathrm{Ag}-\mathrm{P}-\mathrm{Cu}$ systems are stronger than those of $\mathrm{Ag}-\mathrm{Cu}-\mathrm{Zu}-\mathrm{Cd}$ systems at the temperature under $250^{\circ} \mathrm{C}$ but at over $250^{\circ} \mathrm{C}$, the opposste is true.

4) The influences of work hardening on the strength of $\mathrm{Ag}-\mathrm{P}-\mathrm{Cu}$ systems are eliminated at $250^{\circ} \mathrm{C}$, but on that of $\mathrm{Ag}-\mathrm{Cu}-\mathrm{Zn}-\mathrm{Cd}$ systems they remain a little at $500^{\circ} \mathrm{C}$.

The mechanical properties at elevated temperatures have been improved by work hardening and the effect of the latter is remarkable with an increasing $\mathrm{Ag}$ content.

\section{1.まえがき}

ロウ付部の強度に関しては数多くの報告があるが，口 ウ付部の機械的性質とロウ材自身の性兵との関連性に関 する系統的研究は少なく，わずかに Brooker ${ }^{12}$ はロウ 付部強度は使用するロウ材の鋳造状態汇おける強度に等 しいとのべており，Leach あるいは Case などはロウ付 間陌の方を重視している．接合部の口ウ付強度に関する 要因としては母材強度, ロウ材のなじみ性, 接合部のフ ラックス介在，苟るいは空隙，負荷が加わった時の構造 物の㙨械的特性などが考えられる.しかし口ウ材そのも のの強度に関してはその重要性が第二義的とされてい る.たとえば2゙ロウが母材より硬ければ母材から破壊し 軟かけれれ゙接合部から破壊し，それ以外は他の要因によ るとしており，いっぽう Munse および Crawford ${ }^{3)}$ どはロウ材自身の強度を常温, 高温および低温で測定し ているが接合試片を使用してのものであり母材の影響が 入っている.また Munse および Alagia市が行なった 銅合金の口ウ付部強度の研究では口ウ材の強さは接合部

* 原稿受付, 昭和38年 8 月 7 日（昭和 37 年度溶接学会秋乎全国大会似 おい, (発衣)

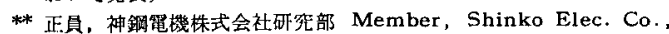
Ltd. Res. Lab.
強度のバラッキを考えると無視してよい範囲であると報 告している。しかし， ロウ付部の高温強度を問題にする ようなときには口ウ材そのものの機械的性質の解明が必 要になる，したがって，著者らは口市付敒関する基礎的 研究の一つとして, $\mathrm{P}-\mathrm{Cu}$ 系, $\mathrm{Ag}-\mathrm{P}-\mathrm{Cu}$ 系, $\mathrm{Cu}-\mathrm{Zn}$ 系 および $\mathrm{Ag}-\mathrm{Cu}-\mathrm{Zn}-\mathrm{Cd}$ 系のロウ材 9 種類について, 常 温および高温に扔ける引張強さ，伸びおよび硬さを検討 し，また常温加工歪の高温強度におよぼす影響などにつ いても考察した。

\section{2. 実験方 法}

\section{1 試料}

試料の種類は Table 1 にしめすように 9 種類の代表 的ロウ材を選んだ。引張試験に用いた試料は黒鉛ルッボ 中で高周波電気炉を用いて溶解し，20 $\mathrm{mm}$ 角の 1 2 $\mathrm{kg}$ の金型中でインゴットを作り，4申まで約 $300^{\circ} \mathrm{C}$ で熱 間圧延し，ついで 1 回の加工度約15\%として線引きを行 ない $450^{\circ} \mathrm{C} \sim 500^{\circ} \mathrm{C}$ で中間燒鈍をおこないながら平均 50\%の加工をしたもので，加工度による特性差をなくす るために Table 2 にしめすごとく，それぞれの固相線 温度より約 $30 \sim 50^{\circ} \mathrm{C}$ 低い温度で, 酸化防止霛囲気中 で焼鈍を行なった後, Fig. 1 に示すような形状に仕上 
Table 1 Chemical composition of brazing alloys

\begin{tabular}{c|l|l|l|l|l|l|l}
\hline \hline \multirow{2}{*}{ Type } & \multirow{2}{*}{ Name } & \multirow{2}{*}{ Size } & \multicolumn{3}{|c}{ Chemical composition \% } \\
\cline { 5 - 8 } & & & $\mathrm{Ag}$ & $\mathrm{P}$ & $\mathrm{Cu}$ & $\mathrm{Zn}$ & $\mathrm{Cd}$ \\
\hline \multirow{3}{*}{ Ag-P-Cu } & BCuP-2 & $2.4 \phi$ & - & 7.24 & 92.72 & - & - \\
& BCuP-6 & $3.2 \phi$ & 2.00 & 5.81 & 92.11 & - & - \\
& BCuP-3 & $2.4 \phi$ & 4.78 & 5.01 & 90.01 & - & - \\
& BCuP-5 & 3.4 & 15.116 .01 & 78.84 & - & - \\
\hline \multirow{3}{*}{ Ag-Cu-Zn-Cd } & LAg-15 & $1.6 \phi$ & 14.34 & - & 49.08 & 26.78 & 9.79 \\
& LAg-25Cd & $1.6 \phi$ & 24.5 & - & 42.11 & 18.15 & 15.14 \\
& BAg-2 & $1.6 \phi$ & 34.24 & - & 20.18 & 28.16 & 17.41 \\
& BAg-1 a & $2.0 \phi$ & 48.90 & - & 19.41 & 14.20 & 17.45 \\
\hline Cu-Zn & BCuZn-1 & $4.0 \phi$ & - & - & 60.00 & 39.40 & - \\
\hline
\end{tabular}

Table 2 Annealing of brazing alloys

\begin{tabular}{c|c|c|c|c}
\hline No. & Name & $\begin{array}{c}\text { Annealing } \\
\text { temp. }\end{array}$ & $\begin{array}{c}\text { Holding } \\
\text { time }\end{array}$ & Atmosphere \\
\hline 1 & $\mathrm{BCuP}-2$ & $650^{\circ} \mathrm{C}$ & $6 \mathrm{Hr}$ & reducing \\
2 & $\mathrm{BCuP}-6$ & $620^{\circ} \mathrm{C}$ & $6 \mathrm{Hr}$ & reducing \\
3 & $\mathrm{BCuP}-3$ & $620^{\circ} \mathrm{C}$ & $6 \mathrm{Hr}$ & reducing \\
4 & $\mathrm{BCuP}-5$ & $620^{\circ} \mathrm{C}$ & $6 \mathrm{Hr}$ & reducing \\
5 & $\mathrm{LAg}-15$ & $600^{\circ} \mathrm{C}$ & $6 \mathrm{Hr}$ & reducing \\
6 & $\mathrm{LAg}-25 \mathrm{Cd}$ & $580^{\circ} \mathrm{C}$ & $6 \mathrm{Hr}$ & reducing \\
7 & $\mathrm{BAg}-2$ & $550^{\circ} \mathrm{C}$ & $6 \mathrm{Hr}$ & reducing \\
8 & $\mathrm{BAg}-1 \mathrm{a}$ & $580^{\circ} \mathrm{C}$ & $6 \mathrm{Hr}$ & reducing \\
9 & $\mathrm{BCuZn-1}$ & $500^{\circ} \mathrm{C}$ & $6 \mathrm{Hr}$ & inert \\
\hline
\end{tabular}

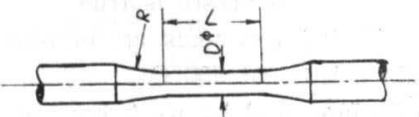

$$
\begin{array}{ll}
L=3.54 D & L ; \text { Gage length } \\
R \geq 15 & D ; \text { Diameter }
\end{array}
$$

Fig. 1 Tension test specimen
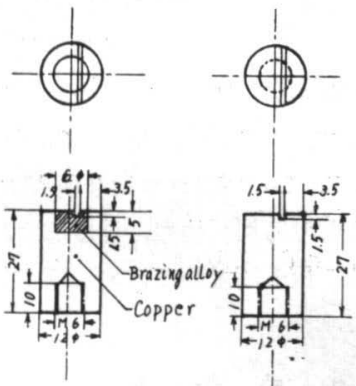

(a) Brazingalloyspecimen (b) Copper specimen

Fig. 2 Hardness test specimen

げた。また硬度測定用試験片は高温硬さ試験装置の関係 で Fig. 2(a) にしめす形状の純銅製ホルダーにロウ材 を鋳造して，熱処理をほどてさないで，そのまま仕上げ た後の硬さを測定した．その熱処理効果を試験するため に BCuP-5 については, Table 2 にしめすごとき焼鈍 を行なった後の硬さも測定した，また電気純銅について は Fig. 2(b) にしめす形状とし冷間加工材および狫鈍 材の硬さも測定した.

\section{2 試料の顕微鏡組織}

引張試験に供した焼鈍後の試料の顕微鏡組織を Fig. 3 にしめす.

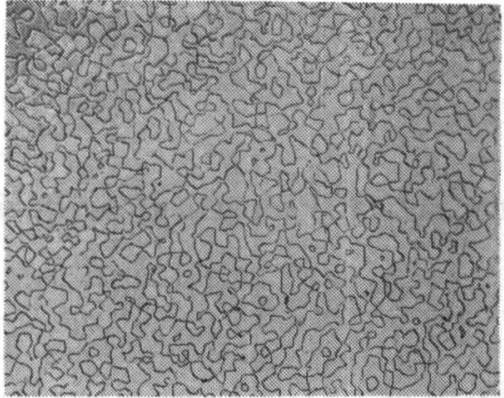

$\mathrm{BCuP}-2$

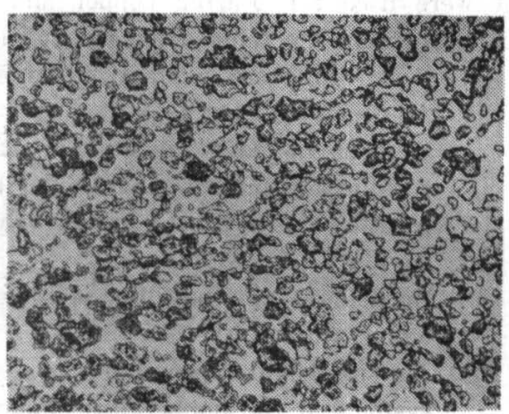

$\mathrm{BCuP}-6$

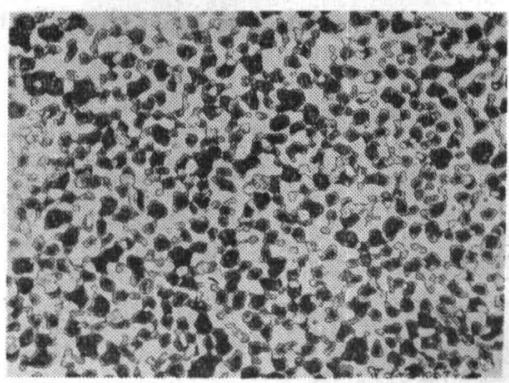

$\mathrm{BCuP}-3$

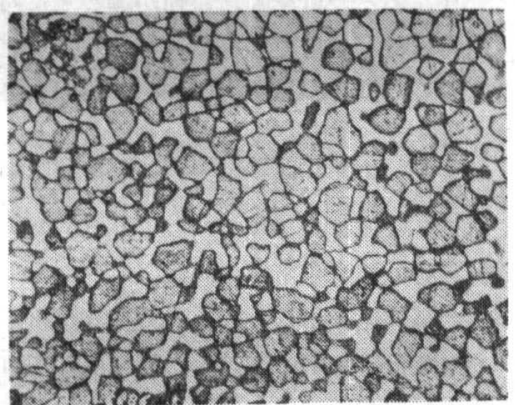

$\mathrm{BCuP}-5$

Fig. 3 Micro-structure of specimens (continued) 


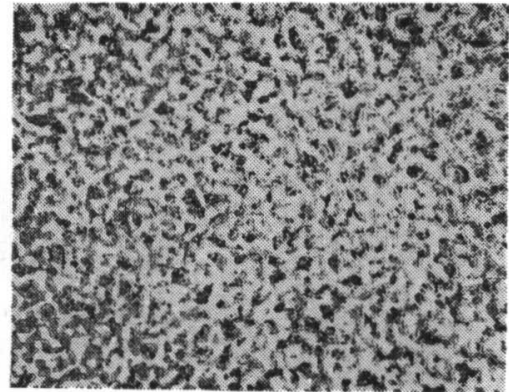

LAg-15

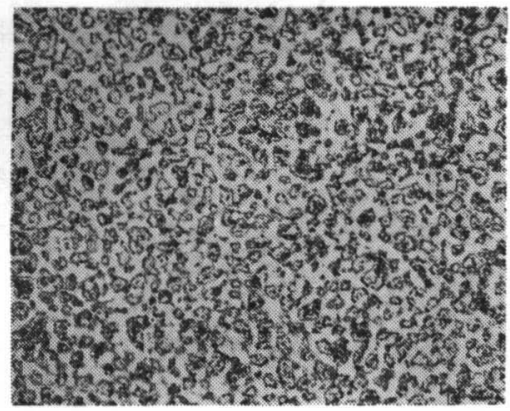

$\mathrm{LAg}-25 \mathrm{Cd}$

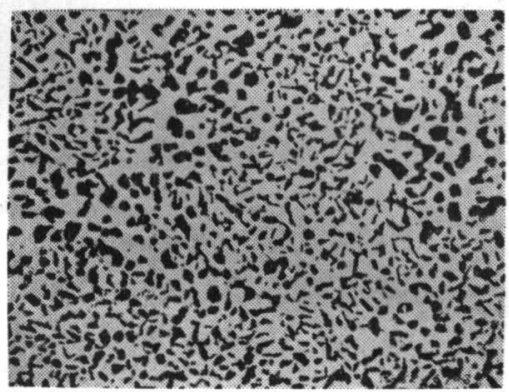

$\mathrm{BAg}-2$

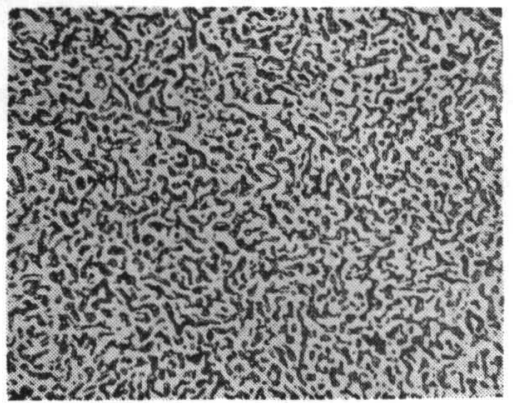

BAg-1 a

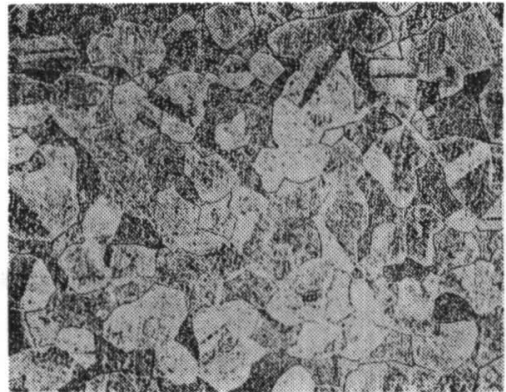

BCuZn-1

Magnification $500 \times \frac{1}{2}$

Etching solution

$$
\begin{array}{r}
\mathrm{NH}_{4} \mathrm{OH}(28 \%) \cdots 1 \\
\mathrm{H}_{2} \mathrm{O} \cdots \cdots \cdots 1 \\
\mathrm{H}_{2} \mathrm{O}_{2}(3 \%) \cdots 1
\end{array}
$$

Fig. 3 Microstructure of specimen

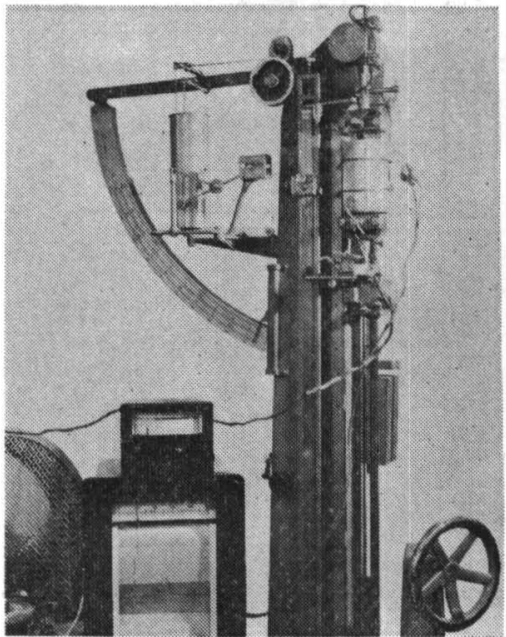

Fig. 4 Tension test apparatus

\section{3 試験装置亡実験条件}

2.3 .1 高温引張試験

Fig. 4 にしめすごときショッパー型引張試験機を用 いて約 $1 \mathrm{KW}$ 容量の環状電気炉を据えつけその中央部 に試料を插入して武験を行なった，温度は試料の平行部 にアルメルクロメル熱電対を装着し, 試料は試験温度に 達するのに抻入後 6 ～8 分を要しており保持時間は後述 するごとく約15分経過後は引張強さに変化が見られない ので各試料と屯に15分にした. な书試料の近傍の炉内温 度の試験中の変動は $\pm 5^{\circ} \mathrm{C}$ 以内である. 試料数は各条 件について $3 \sim 5$ ケを用いた。試験温度は常温, $80^{\circ} \mathrm{C}$, $120^{\circ} \mathrm{C}, 200^{\circ} \mathrm{C}, 240^{\circ} \mathrm{C}, 300^{\circ} \mathrm{C}$, および $400^{\circ} \mathrm{C}$. とした.

\section{3 .2 高温硬さ陚験}

日本光学製高遠式高温微小硬度計を用い試料の加熱炬 内は真空雾囲気にしその真空度は $1 \times 10^{-4} \sim 3 \times 10^{-4} \mathrm{~mm}$ $\mathrm{Hg}$ にした. 熱電対はアルメルロメルを用いて試料に密 着させ測定中の温度は $\pm 3^{\circ} \mathrm{C}$ 以内に制御した. 測定荷 重は $300 \mathrm{~g}$ とし負荷時間は 30 秒, 圧子はダイヤモンド 

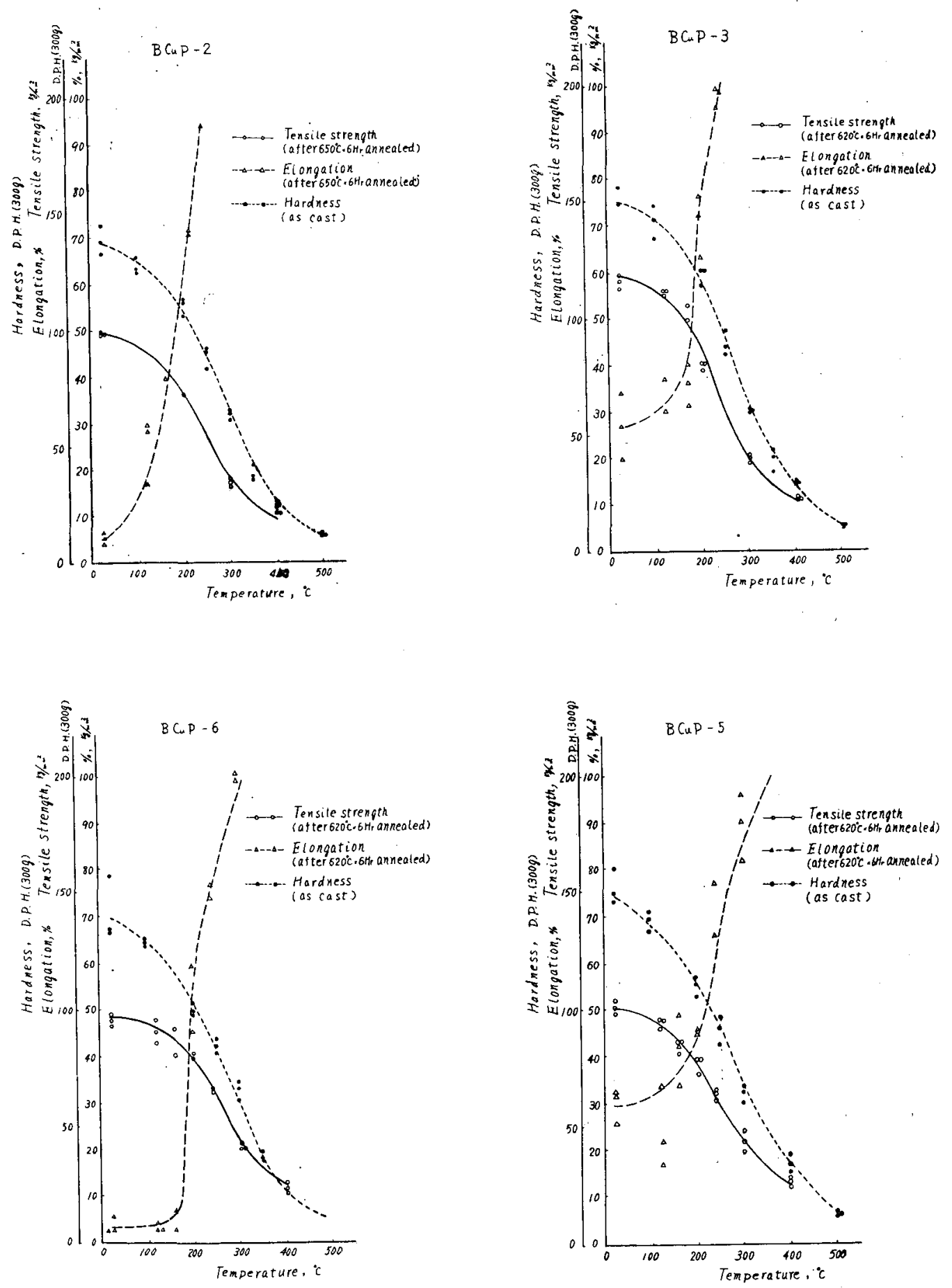

Fig. 5 Mechanical properties at elevated temperature (Continued) 

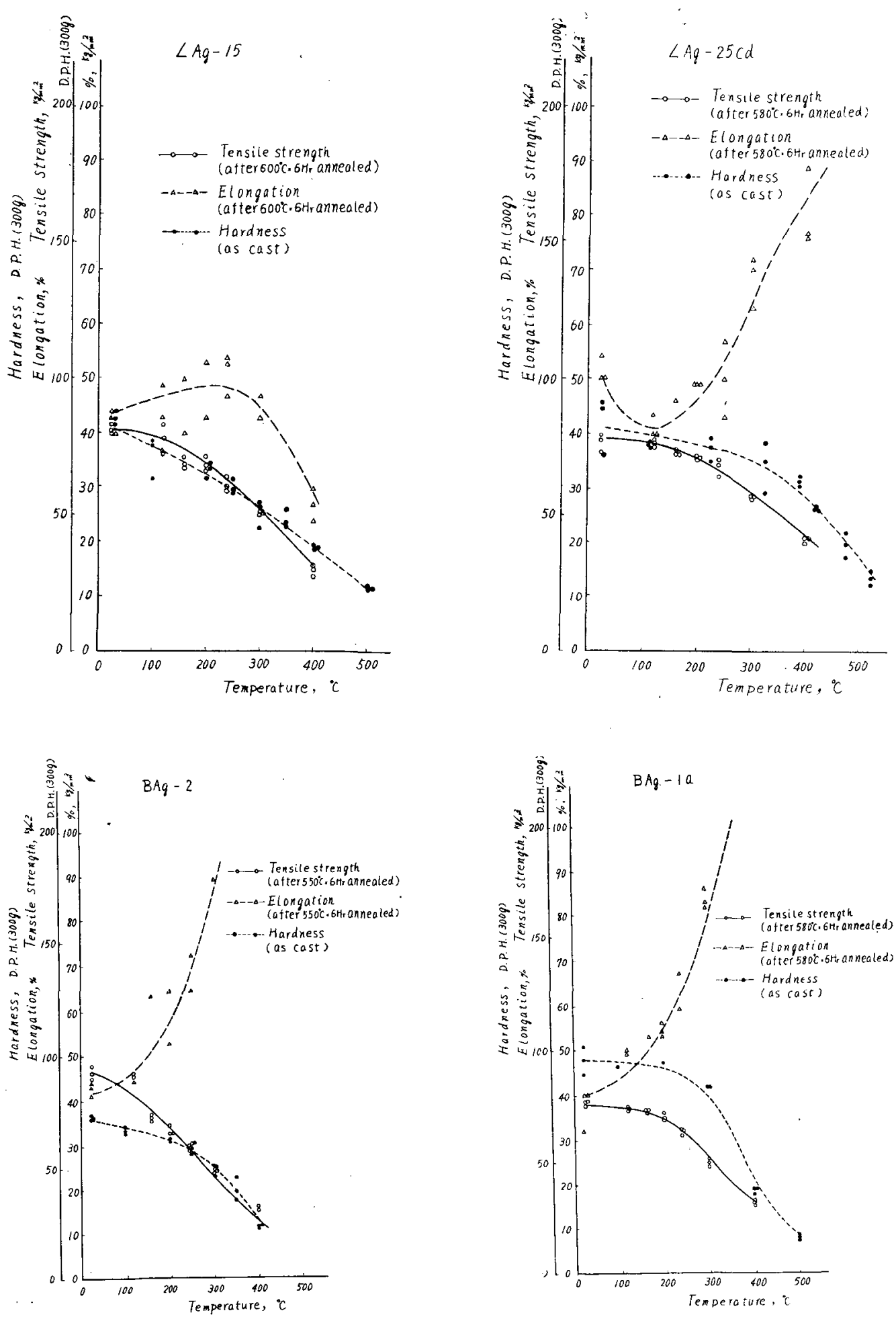

Fig. 5 Mechanical properties at elevated temperatures (Continued) 


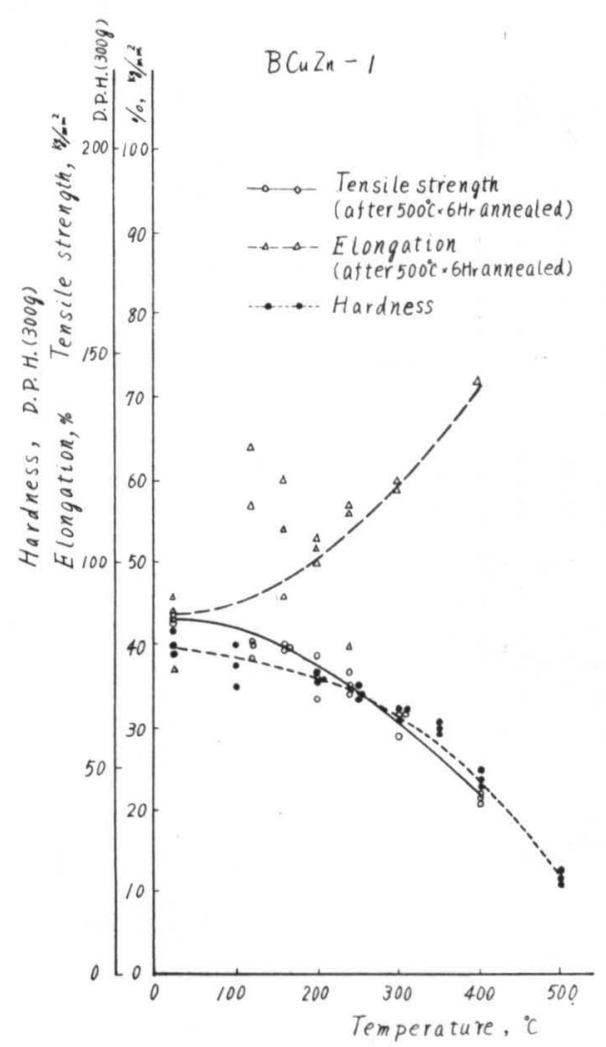

Fig. 5 Mechanical properties at elevated temperatures

を用い昇温速度は $10 \sim 20^{\circ} \mathrm{C} /$ 分とし試験温度は試料の 種類によって多小異なるが $100^{\circ} \mathrm{C}, 200^{\circ} \mathrm{C}, 300^{\circ} \mathrm{C}, 400$ ${ }^{\circ} \mathrm{C}$, および $500^{\circ} \mathrm{C}$ とし測定は温度上昇時についてのみ 行ない試験温度に到達するまでの昇温は急速に行ない保 持時間は後述するごとく15分とし $3 \sim 5$ 点について硬さ を測定してその平均值を試験温度における硬さとした。

\section{3. 実験結果および考察}

高温引張強さ, 伸びおよび硬さの測定結果を Fig. 5 にしめす. Fig. 6 に引張試験後の破断面の一例をしめ す.

\section{1 保持時間の影響}

高温引張試験に対する保持時間の影響については, $\mathrm{BAg}-2$ を用いて $300^{\circ} \mathrm{C}$ に保持し時間を 5 〜0分の間で 変化して引張強さを測定した. その結果を Fig. 7 にし めすが15分以上保持すればその值がほとんど一定である ことがわかった. 同様にして硬さに関しては BCuP-5 の試料を焼鈍後 $100^{\circ} \mathrm{C}, 300^{\circ} \mathrm{C}$ お よび $500^{\circ} \mathrm{C}$ につて それぞれ10 60 分間保持後測定した. その結果は Fig. 8 にしめすごとく15分以上保持すれば十分であることが わかった.

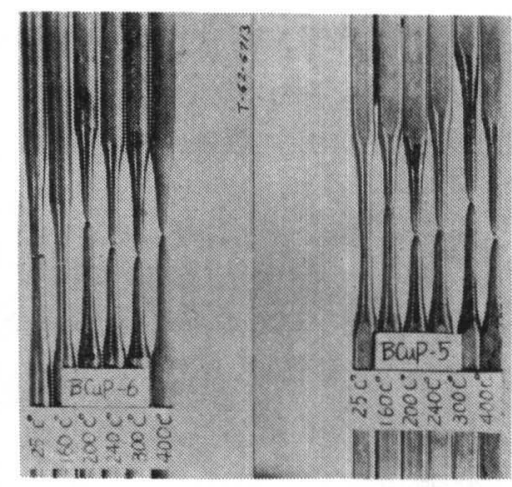

Fig. 6 A view of fracture surface of tensile specimen at elevated temperatures

$$
\begin{aligned}
& \text { Condition } \\
& \text { Material } ; B n y-2 \\
& \text { Heat treatmeni } ; 550^{\circ} \mathrm{C} \cdot 6 \mathrm{Hr} \text { annealed } \\
& \text { Test temperature; ot } 300^{\circ} \mathrm{C}
\end{aligned}
$$

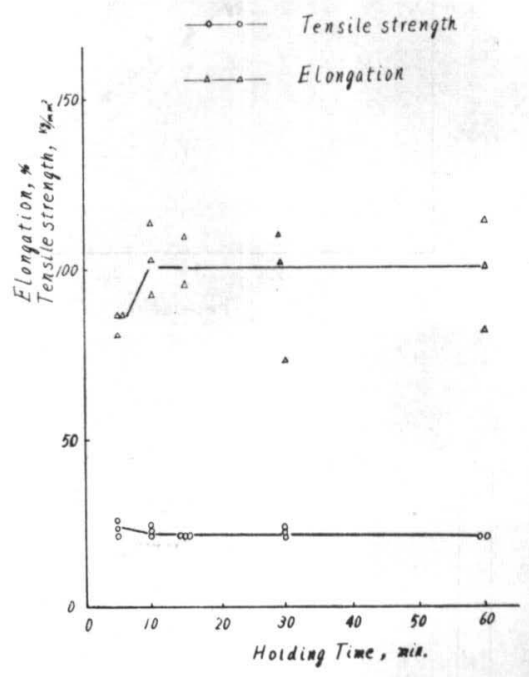

Fig. 7 Effect of holding time upon tensile strength and elongation

\section{2 Ag-P-Cu 系について}

高温引張強さは $\mathrm{BCuP}-2$ のみ他の含銀口ウに比較し て $100^{\circ} \mathrm{C}$ 以上で約 $10 \%$ 程度劣っており, 約 $250^{\circ} \mathrm{C}$ 以 下では Ag 5\% の BCuP-3 があっとも優れておりそれ 以上では Ag の多い BCuP-5 が優れている. 高温硬度 は全温度域で Ag 5\% 以上のものがわずか硬いがとくに 顕著な差は見られなかった. 伸びについては $\mathrm{Ag}$ の含有 量の効果が比較的顕著で $150^{\circ} \mathrm{C}$ 以下の伸びは $\mathrm{Ag} 2 \%$ 以下のものはかなり低く注意を要する．乙れらの試験結 果から Ag は常温での柔軟性をあたえ, また高温強度に わずか寄与しているととがわかる。しかし予想されたほ ど大きな特性差は見られなかった。 
condition.

Material ; BCap-5

Heat treatment; $620^{\circ} \mathrm{C}$. $5 \mathrm{Hr}$ annealed.

(1) at $100^{\circ} \mathrm{C}$

(2) at $300^{\circ} \mathrm{C}$

(2) at $500^{\circ} \mathrm{C}$

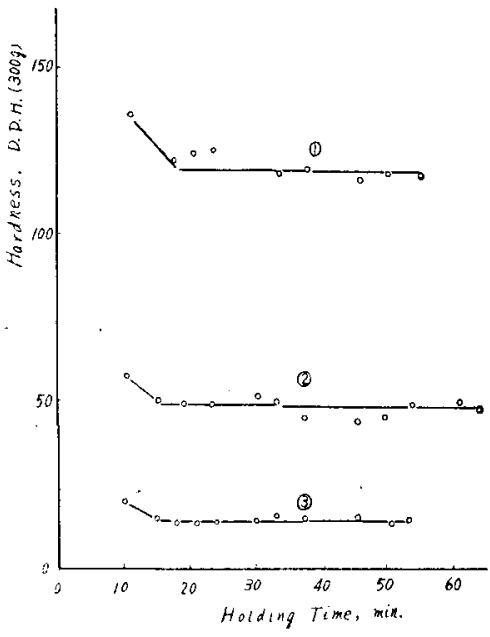

Fig. 8 Effect of holding time upon hardness

\section{3 Ag-Cu-Zn-Cd 系について}

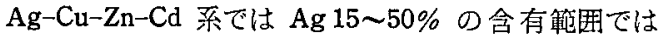
一義的な関係はみられす概して Ag 25\% の LAg-25 Cd が優れている. BAg-2 と BAg-1 a では引張強さは 150 ${ }^{\circ} \mathrm{C}$ 以下で前者が強いがそれ以上の温度ではわずかに後 者が優れているようである，伸びは Ag 25 50\% では 変らないが Ag 15\%のものでは約 $200^{\circ} \mathrm{C}$ を超えると減 少している.この原因について析出硬化ではないかと調 查したが現在のところ他の理由によるようである。また 黄銅口ウは他の含銀四元銀口ウに比較して高温強度は全 般に優れている，鋳造したままでの高温硬度は約 $300^{\circ} \mathrm{C}$ までは、BAg-1 a が高く $350^{\circ} \mathrm{C}$ を超えると $\mathrm{Ag} 25 \%$ の LAg-25.Cd が優れている. BAg-1 a と BAg-2 では全 体的に BAg-1 a のほうが硬い, 以上の点から高温強度 としては $\mathrm{Ag} \mathrm{25 \%}$ 程度の $\mathrm{Ag}-\mathrm{Cu}-\mathrm{Zn}-\mathrm{Cd}$ 系のものがも っとも優れており，ついで BAg-1 a, BAg-2, と考えら れるが，Ag\% による大きな特性差は見られない。

\section{$3.4 \mathrm{Ag}-\mathrm{P}-\mathrm{Cu}$ 系と $\mathrm{Ag}-\mathrm{Cu}-\mathrm{Zn}-\mathrm{Cd}$ 系の高温特} 性の差について

引張強さは略 $250^{\circ} \mathrm{C}$ を境界にしてそれ以下では $\mathrm{Ag}$ $\mathrm{P}-\mathrm{Cu}$ 系が優れておりそれ以上では $\mathrm{Ag}-\mathrm{Cu}-\mathrm{Zn}-\mathrm{Cd}$ 系 が優れている. Fig. 9 にその状況をしめす. 伸びは略 $200^{\circ} \mathrm{C}$ を境にして低温では逆である. Fig. 10 にその状 況をしぬす. 硬度は引張強さより顕著な差をしめし略 $250^{\circ} \mathrm{C}$ を境にして低温では $\mathrm{Ag}-\mathrm{P}-\mathrm{Cu}$ 系が非常に高く
- Ag-P- Co type alloys

-... Ag-Cu-Zn-Cd and Cu-Zn type alloys

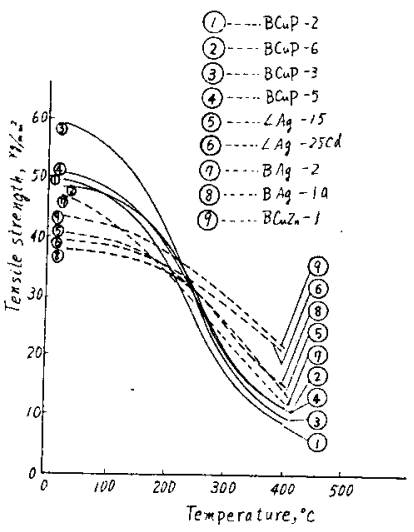

Fig. 9 Tensile strength of various brazing alloys at elevated temperatures

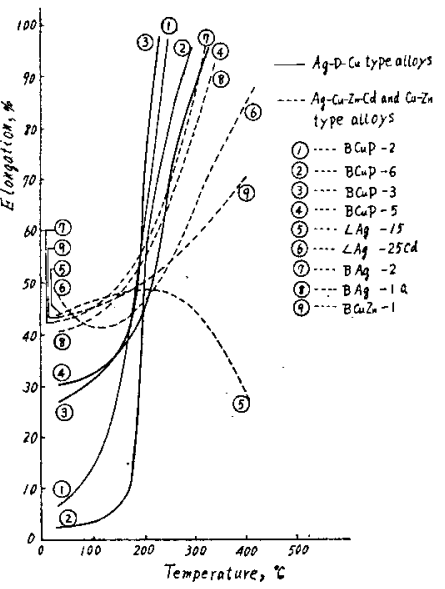

Fig. 10 Elongation of various brazing alloys at elevated temperatures

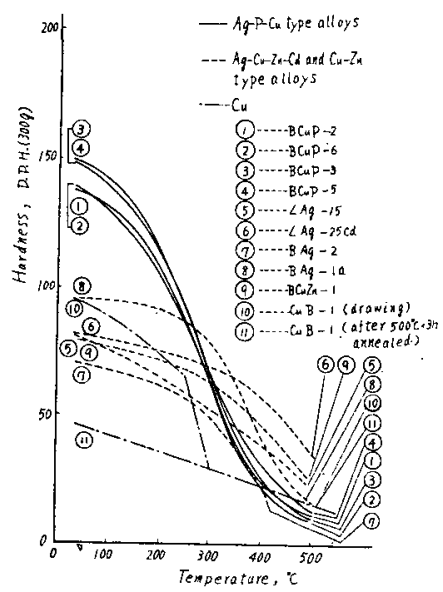

Fig. 11 Hardness of various brazing alloys and copper at elevated temperatures 
それ以上では逆に低くなる．その状況は Fig. 11 にし めすが硬度試験片も焼鈍を十分行なえば引張強さの傾向 と類似してくるすのと考えられる.

\section{5 高温特性におよばす加工歪の影響}

加工硬化比よる内部歪あるいはその他の内部応力を有 する試料で高温特性を測定すれば当然これらの応力弛緩 による特性変化が高温性質の中に加味されてくる．Fig， 12 は電気銅 $\mathrm{CuB} 1-\mathrm{H}$ (硬質) のものと $500^{\circ} \mathrm{C} \times 3 \mathrm{Hr}$. の再結晶焼鈍後の試料に上る高温硬さをしめす。これは 約 $300^{\circ} \mathrm{C}$ で一致しているが Fig. 13 にしめすでとく BCuP-5 について硬度測定用に鋳込んだままのものと， $620^{\circ} \mathrm{C} \times 6 \mathrm{Hr}$. 陞鈍したものでは $500^{\circ} \mathrm{C}$ に達するまで硬 度差を有しており，加工硬化あるいは内部歪は高温強度 にかなり影響を有している，また高温引張強さにおよに゙

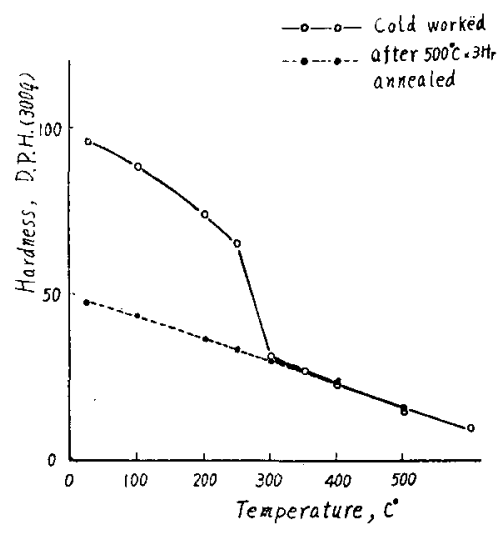

Fig. 12 Effect on hardness at elevated temperatures with annealing

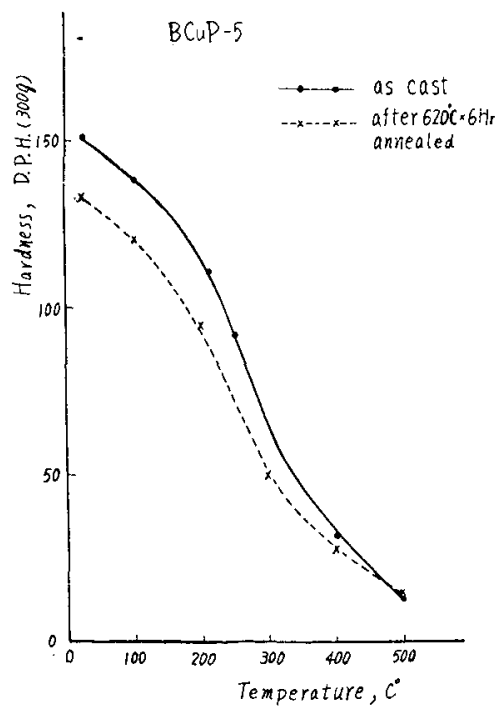

Fig. 13 Effect on hardness at elevated temperatures with annealing

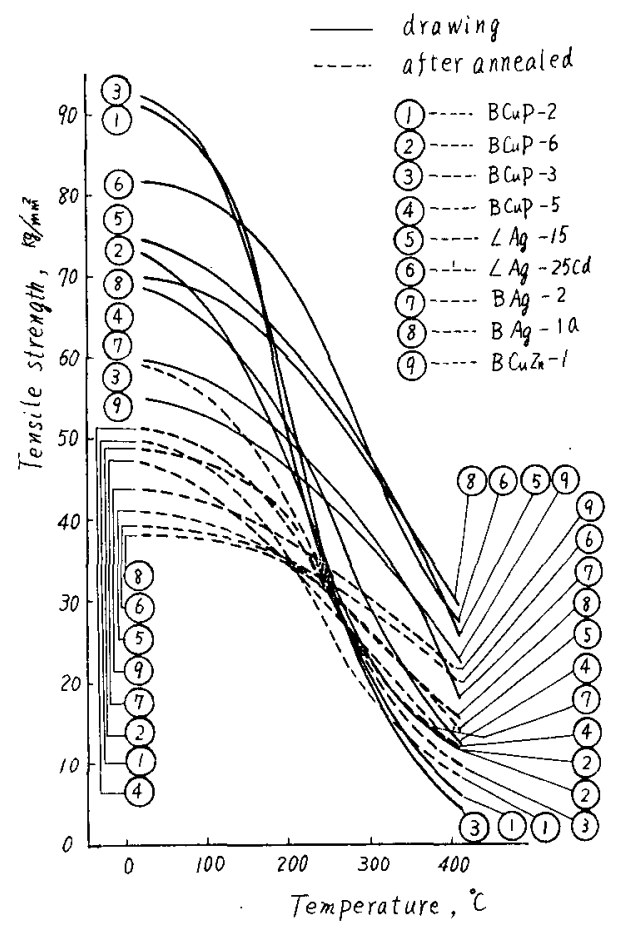

Fig. 14 Effect on tensile strength at elevated temperatures with annealing

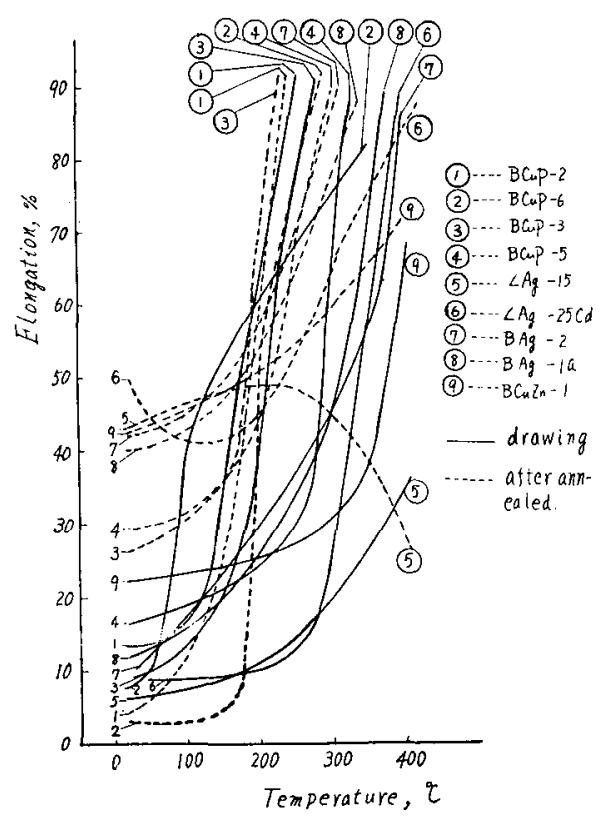

Fig. 15 Effect on elongation at elevated temperatures with annealing 
す各種の口ウ材の加工歪の効果を Fig. 14 にしめす. 試料の加工度がほぼ一様であるとすれば $\mathrm{Ag}-\mathrm{Cu}-\mathrm{Zn}-\mathrm{Cd}$ 系では高温まで加工歪による効果が残って強度を大にし ており，いっぼう純銅および $\mathrm{Ag}-\mathrm{P}-\mathrm{Cu}$ 系のむのは約 $250^{\circ} \mathrm{C}$ でほほ加工歪の影響が見られなくなっている。 のことは $\mathrm{Ag}$ の含有量の多少と関係があるように考え られ，Ag\% の高いロウ材では常温加工時の加工歪が高 温における強度を保持するのに役立ち $\mathrm{Ag} \%$ の低いる のほどその消滅が早いようである．これは再結晶速度が $\mathrm{Ag} \%$ の増加するこよにより遅れることを意味する．こ のこよは Fig. 15 にしめすように伸びについてもほぼ 同様なととが観察される。これれいウ付接合部の高温強 度を考えるとき一般化口接部はなんらかの内部歪が存 在するはずであり， Ag 含有量の高い口ウ材を用いれば 高温特性が優れているとと屯推定される.しかしてのこ とは略 $250^{\circ} \mathrm{C}$ 以上で若えられることで，それ以下では 常温加工歪はいかなるロウ材においても強度を増加させ るものである.

\section{4. 結論}

銅㧍よび銅合金のロウ付を対象にしたロウ材各種につ いて高温における機械的性質を検討した結果つぎのごと く要約される.

i)，高温引張強さあるいは硬さを测定するときの試料 保持時間は焼鈍された試料であれば15分以上でよい，

ii)，Pを $5 \sim 7 \%$ 含む $\mathrm{Ag}-\mathrm{P}-\mathrm{Cu}$ 系の焼鈍後の口ウ 材では $\mathrm{Ag}$ の量が 0 15\%に変わると $\mathrm{Ag}$ 量の増加と ともに常温での柔軟性が堌し高温強度も約10\%程度改善
される. 約 $250^{\circ} \mathrm{C}$ 以下では $\mathrm{Ag} 5 \%$ のむのが優れ，そ れ以上では Ag 15\% のものが優れておう $\mathrm{Ag} 2 \%$ 以下 のものは $150^{\circ} \mathrm{C}$ 以下での伸びがとくに低い，

iii), $\mathrm{Ag}-\mathrm{Cu}-\mathrm{Zn}-\mathrm{Cd}$ 系の焼鈍後の口ウ材では，高温 強度と $\mathrm{Ag} \%$ の間化一定の関係がなく， $\mathrm{Ag} 25 \%$ 程度 のものが優れており，ついで Ag 50\% (BAg-1 a), Ag 35\%（BAg-2）の順となり， Ag\% による大きな特性の 差は見られない。

iv)，焼鈍後の $\mathrm{Ag}-\mathrm{P}-\mathrm{Cu}$ 系之 $\mathrm{Ag}-\mathrm{Cu}-\mathrm{Zn}-\mathrm{Cd}$ 系では その高温特性がほ济 $250^{\circ} \mathrm{C}$ を境界にして変化し, $250^{\circ} \mathrm{C}$ 以下では前者が引張強さおよび硬度が大で伸びは少なく 後者は $250^{\circ} \mathrm{C}$ 以上で優れている.

v), 常温加工歪を有する $\mathrm{Ag}-\mathrm{P}-\mathrm{Cu}$ 系口ウ材では約 $250^{\circ} \mathrm{C}$ で加工歪の影響が消滅する. Ag-Cu- $\mathrm{Zn}-\mathrm{Cd}$ 系で は $\mathrm{Ag}$ の含有量の多いロウ材ほど内部歪が高温におけ る強度を保持するのに役立ち口ウの高温特性 $\left(250^{\circ} \mathrm{C}\right.$ 以上）を改善することが考えられる。

\section{参考 文 献}

1) Brooker $\xi$ Beatson, "Industrial Brazing", London (1954), p. 143.

2) AWS, "Welding Hand Book," New York, (1956).

3) W.H. Munse and D.C. Crawford, "Filler Metal Strength in Brazed Copper Joint," W.J. Vol. 34 (1955), No. $2105 \mathrm{~s}-111 \mathrm{~s}$.

4) W.H. Munse and J.S. Alagia, "Strength of Brazed Joints in Copper Alloys," W.J. Vol. 36 (1957), No. 4, $177 \mathrm{~s}-184 \mathrm{~s}$.

5) F.M. Miller and R.L. Peaslee, "Proposed Procedure for Testing Shear Strength of Brazed Joints," W.J. Vol. 37 (1957), No. 4,144 s-150s.

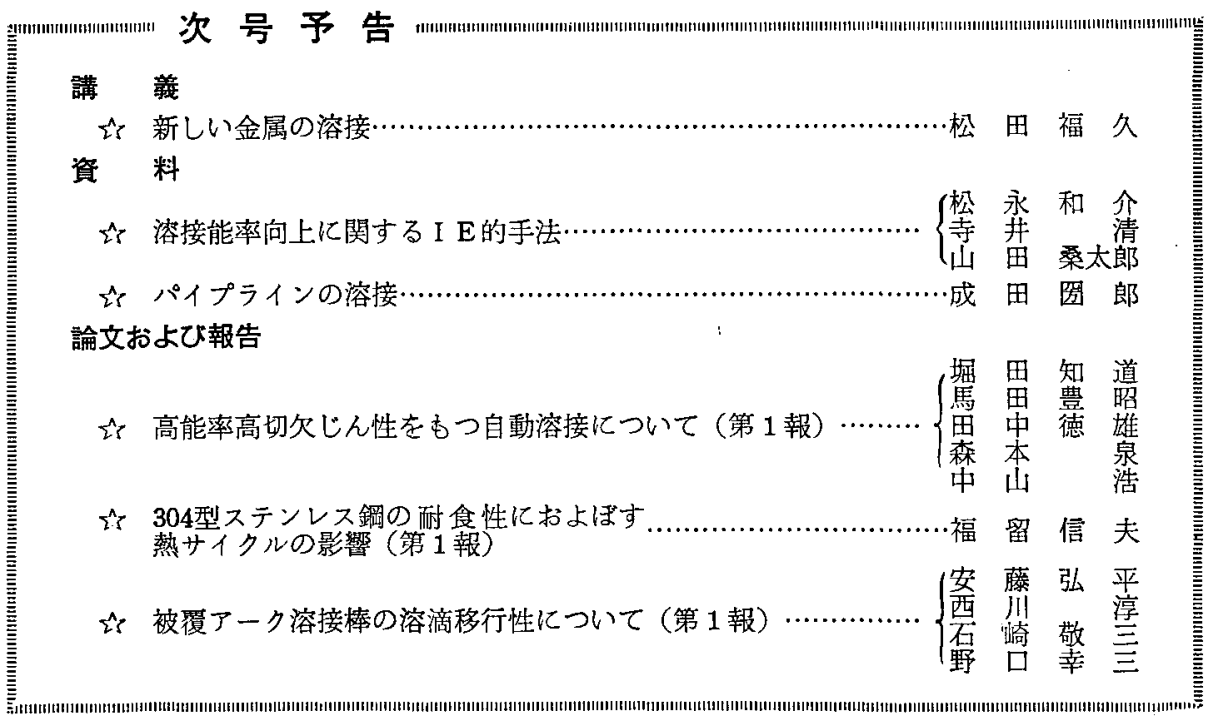

